\title{
MENGEMBANGKAN KETERAMPILAN BERBICARA PADA ANAK USIA DINI MELALUI METODE SOSIODRAMA
}

\author{
Vichy Variansi ${ }^{1}$ \\ Ernalis $^{2}$ \\ Nono Harsono ${ }^{3}$
}

\begin{abstract}
ABSTRAK
Penelitian ini dilatarbelakangi karena adanya permasalahan yang ditemukan di PAUD Tunas Unggulan yaitu kemampuan keterampilan berbicara yang kurang baik. Selain itu juga pembelajaran yang masih konvensional. Penelitian ini bertujuan untuk mengetahui bagaimana proses pembelajaran dengan menggunakan metode sosiodrama, bagaimana aktivitas belajar anak pada pembelajaran berbicara dengan menggunakan metode sosiodrama, dan bagaimana hasil keterampilan berbicara pada anak dengan menggunakan metode sosiodrama di Paud Tunas Unggulan Kelompok B2. Penelitian ini merupakan bentuk Penelitian Tindakan Kelas (PTK) model Jhon Elliot. Berdasarkan hasil penelitian pada siklus I proses pembelajaran yang dilakukan anak masih kurang aktif, anak tidak berani tampil didepan karena malu. Pada siklus II anak sudah mulai memahami pembelajaran yang dilakukan dan berani untuk tampil didepan. Pada siklus III anak mengikuti pembelajaran dari awal sampai akhir dan anak juga mulai memahami pembelajaran, sudah tidak merasa malu lagi untuk tampil didepan. Dari proses pembelajaran dari masing-masing siklus menunjukan bahwa dengan menggunakan metode sosiodrama keterampilan berbicara anak mengalami perkembangan. Hal ini juga didukung oleh presentase peningkatan jumlah yang dikategorikan berkembang sangat baik. Perkembangan keterampilan berbicara anak pada siklus I tindakan I yang mendapatkan bintang 3 sebanyak $0 \%$, pada tindakan II $0 \%$, tetapi ada perkembangan pada tindakan III sebesar 13,33\%. Pada siklus II tindakan I yang mendapatkan bintang 3 sebanyak 17,65\%, pada tindakan II menjadi 23,53\%, sedangkan pada tindakan 3 sebanyak 29,41\%. Dan pada siklus III tindakan 1 yang mendapatkan bintang 3 sebanyak 35,29\%, meningkat pada tindakan II sebanyak $47,06 \%$, kemudian meningkat lagi pada tindakan 3 menjadi 76,47\%, jumlah nilai keseluruhan siklus $80.91 \%$. Dari hasil penelitian ini, hasil yang didapat dari setiap siklusnya mengalami peningkatan dari setiap siklus tindakannya. Peningkatan ini mencerminkan bahwa dengan menggunakan metode sosiodrama dapat mengembangkan keterampilan berbicara anak.
\end{abstract}

Kata Kunci : metode sosiodrama, keterampilan berbicara

\footnotetext{
${ }^{1}$ vichivariansi@yahoo.com

${ }^{2}$ Dosen Kampus UPI Cibiru

${ }^{3}$ Dosen UPI Kampus Cibiru
} 


\section{A. PENDAhuluan}

Pendidikan adalah usaha sadar dan terencana untuk mewujudkan suasana belajar dan proses pembelajaran agar peserta didik secara aktif mengembangkan potensi pada dirinya. Untuk memiliki kekuatan spiritual keagamaan, pengembangan diri, kepribadian, kecerdasan, akhlak mulia, serta keterampilan yang diperlukan dalam masyarakat berbangsa dan bernegara. Tamin (2009) menyebutkan bahwa" tolak ukur keberhasilan pendidikan adalah seberapa jauh usaha pendidikan itu dapat memberikan ruang dan fasilitas yang lebih luas bagi pengembangan kepribadian dan kebebasan bermasyarakat "pendidikan juga merupakan suatu proses sadar untuk mengembangkan potensi individu sehingga memiliki kecerdasan pikir dan emosi, berwatak mulia dan mempunyai keterampilan untuk siap hidup ditengah- tengah masyarakat. Oleh karena itu, pendidikan sangat dibutuhkan oleh anak dari kandungan sampai dewasa.

Sesuai dengan tujuan pendidikan di atas, pendidikan anak usia dini (PAUD) secara umum memiliki tujuan untuk membentuk anak indonesia yang berkualitas, yaitu anak yang tumbuh dan berkembang sesuai dengan tingkat perkembangannya sehingga memiliki kesiapan yang optimal dalam memasuki pendidikan dasar, mengarungi kehidupan di masa dewasa serta membantu menyiapkan anak mencapai kesiapan belajar (akademik) di sekolah Taman kanak-kanak merupakan salah satu jenjang pendidikan anak usia dini.

Pendidikan anak usia dini (PAUD) adalah jenjang pendidikan sebelum jenjang pendidikan dasar yang merupakan suatu upaya pembinaan yang ditujukan bagi anak sejak lahir sampai dengan usia 6 tahun yang dilakukan melalui pemberian rangsangan pendidikan untuk membantu pertumbuhan dan perkembangan jasmani dan rohani agar anak memiliki kesiapan dalam memasuki pendidikan lebih lanjut, yang diselenggarakan pada jalur formal, nonformal, dan informal (UUD RI Nomor 20 Tahun 2003).

Penyelenggaraan pendidikan bagi Anak Usia Dini pada jalur formal salah satunya Taman Kanak-kanak (TK) atau RA dan lembaga sejenis, penyelenggaraan pendidikan bagi anak usia dini pada jalur nonformal diselenggarakan oleh masyarakat kebutuhan dari masyarakat sendiri, khususnya bagi anak-anak dengan keterbatasannya tidak terlayani dipendidikan formal (TK dan RA). Pendidikan dijalur informal dilakukan oleh keluarga atau lingkungan.

Menurut Yuliani-Sujiono (2009, hlm. 22) TK adalah salah satu bentuk satuan pendidikan bagi anak usia dini 4 - 6 tahun. Sasaran, pendidikan TK adalah anak usia 4-6 tahun, yang dibagi kedalam dua kelompok belajar berdasarkan usia yaitu kelompok A untuk usia 4-5 tahun dan kelompok B untuk anak didik usia 56 tahun. Hal tersebut dimaksudkan agar pembelajaran yang diberikan dapat sesuaikan dengan karakteristik anak.

Pendidikan TK diselenggarakan untuk mengembangkan pribadi, pengetahuan, dan keterampilan yang melandasi pendidikan dasar, dan seumur hidup, karena PAUD merupakan fondasi awal dalam meningkatkan kemampuan anak untuk menyelesaikan pendidikan yang lebih tinggi, menurunkan angka mengulang kelas dan angka putus sekolah. Aspek perkembangan anak menjadi tujuan yang utama dalam pendidikan TK (Taman Kanak-Kanak) Aspek-aspek tersebut dapat dikembangkan melalui kegiatan pembelajaran. Aspek kemampuan 
anak yang dikembangkan meliputi bahasa, kognitif, fisik motorik, dan sosial emosional.

Pada rentang usia lahir sampai 6 tahun anak mengalami masa keemasan yang merupakan masa dimana anak mulai peka atau sensitive untuk menerima berbagai rangsangan. Masa peka adalah masa terjadinya kematangan fungsi fisik dan psikis, anak telah siap merespon stimulasi yang diberikan oleh lingkungan. Sedangkan masa peka pada masing-masing anak berbeda, seiring dengan laju pertumbuhan dan perkembangan anak secara individual. Masa ini juga merupakan masa peletak dasar pertama untuk mengembangkan kemampuan kognitif, bahasa, gerak motorik, dan sosio emosional pada anak usia dini (Yuliani- Sujiono 2009, hlm. 2)..

Untuk membentuk anak indonesia yang berkualitas dan pandai berkomunikasi tidak terlepas dari peranan seorang guru. Guru adalah peranan utama dalam menghasilkan pendidikan yang berkualitas, tapi guru bukan satusatunya sumber ilmu pengetahuan. Selain guru hal lain yang perlu dipikirkan dalam menciptakan anak indonesia yang berkualitas dan memajukan proses belajar adalah kurikulum, program- program pendidikan, sumber daya, fasilitas pendidikan, keuangan, manajemen dan kepemimpinan pendidikan. Guru harus melakukan berbagai cara dan harus kreatif mengingat pada umumnya anak TK sering mengalami masalah yang disebabkan masih kurangnya pengetahuan

Berbicara adalah suatu berkata, bercakap, berbahasa atau melahirkan pendapat, dengan berbicara manusia dapat mengungkapkan ide, gagasan, perasaan kepada orang lain sehingga dapat melahirkan suatu interaksi. Sedangkan menurut Tarigan (1986, hlm. 3) berbicara adalah kemampuan seseorang dalam mengucapkan bunyi-bunyi artikulasi atau kata-kata yang bertujuan untuk mengekspresikan, menyatakan serta menyampaikan pikiran, gagasan dan perasaan orang tersebut.

Keterampilan berbicara mempunyai peranan sosial yang sangat penting dalam kehidupan manusia. Karena setiap hari pasti kita melakukan kegiatan berbicara ini. Baik untuk menyampaikan ide, gagasan, pesan, musyawarah dan seterusnya.

Berdasarkan temuan dilapangan selama peneliti melakukan Observasi di TK Tunas Unggulan kabupaten bandung kecamatan gedebage , peneliti sering menemukan guru hanya melakukan kegiatan pembelajaran cenderung serius dan berfokus pada kegiatan akademik seperti membaca, menulis, serta berhitung atau terlalu banyak menggunakan metode pembelajaran yang sama. Mayoritas guru lebih berorientasi pada hasil pencapaian indikator yang ada pada kurikulum bukan pada tahap perkembangan dan kebutuhan anak.

Ada beberapa kendala yang mempengaruhi kurang maksimalnya pembelajaran terutama dalam berbicara yang salah satu diantaranya adalah penerapan metode pembelajaran yang dianggap bosan oleh para anak, Tema dan kegiatan yang digunakan di TK yang satu dengan yang lain sama dan setiap tahun tema yang digunakan tidak pernah berubah. Pembelajaran seperti ini membuat anak merasa jenuh dan kaku belum bisa mengungkapkan ide dan minatnya, proses pembelajaran anak cenderung mencontoh apa yang diberikan oleh guru jadi imajinasi anak tidak berkembang secara optimal, sehingga anak tidak mampu 
berkreatifitas secara optimal. Anak bersifat individualisme dan kurang menghargai teman.

Hal inilah yang membuat peneliti merasa tertarik untuk melakukan penelitian dengan menggunakan metode sosiodrama. Mengingat hal-hal tersebut di atas keterampilan berbicara penting untuk ditingkatkan terutama dimulai sejak anak usia TK. Sosiodrama untuk anak TK PAUD yaitu suatu cara memerankan beberapa peran dalam suatu cerita tertentu yang mrnuntut integrasi diantara para pemeranya yaitu anak-anak usia TK dan PAUD. Sehingga keterampilan berbicara pada anak untuk mengeksplorasi bakat, minat, kemampuan dan ide kegiatan dalam mengungkapkan pendapat tentang apa yang anak ketahui memberikan kesempatan pada anak untuk menciptakan dunianya sendiri dengan cara menghargai segala sesuatu yang diciptakan anak tersebut sehingga anak akan merasa nyaman dan ceria tidak akan merasa takut karena disini peneliti hanya bersifat fasilitator.

\section{B. METODE}

Metode penelitian yang digunakan dalam penelitian kualitatif ini adalah metode Penelitian Tindakan Kelas (PTK), Menurut Arikunto (2014, hlm. 2) bahwa PTK merupakan paparan gabungan definisi dari tiga kata"penelitian, tindakan, dan kelas. (1) Penelitian adalah kegiatan mencermati suatu objek, menggunakan aturan metodologi tertentu untuk memperoleh data atau informasi yang bermanfaat bagi peneliti atau orang-orang yang berkepentingan dalam rangka peningkatan kualitas diberbagai bidang. (2) Tindakan adalah menunjuk pada suatu gerak kegiatan yang sengaja dilakukan dengan tujuan tertentu. Dalam penelitian berbentuk rangkaian siklus kegiatan untuk siswa. (3) Sedangkan kelas adalah dalam hal ini tidak terikat pada pengertian ruang kelas, tetapi dalam pengertian yang lebih spesifik yaitu sekelompok siswa yang dalam waktu yang sama, menerima pelajaran yang sama dari guru yang sama pula.

Model desain penelitian tindakan kelas yang akan di gunakan oleh penulis yaitu model yang dikembangkan oleh John Elliot yang mengadopsi dari konsep model Kurt Lewin. Karena PTK Model John Elliot ini tampak lebih detail dan rinci. Adapun bagan model PTK yang dikemukakan oleh John Elliot yaitu sebagai berikut: 


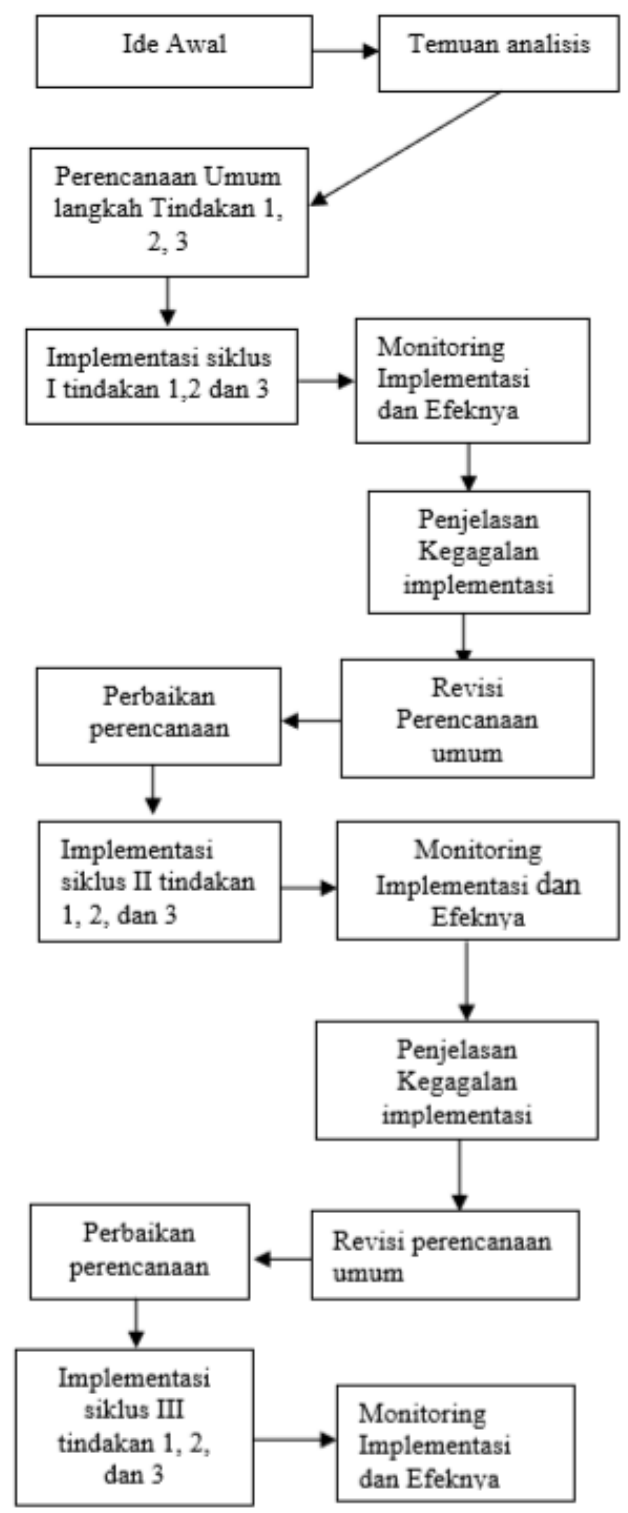

Peneliti mengadakan penelitian yang dilaksanakan bertempat di TK Tunas Unggulan J1 Cemara E Komplek Adipura Kecamatan Gede bage, Subyek penelitian ini adalah anak TK tunas unggulan kelompok B2 yang berjumlah 17 siswa yang terdiri dari 8 anak laki-laki dan 9 anak perempuan

Pada penelitian ini peneliti menggunakan teknik pengumpulan data dengan cara observasi, dokumentasi, dan wawancara. Setelah data yang diperlukan dalam penelitian terkumpul, maka akan dilakukan analisis data. Sebelum data-data dianalisis peneliti terlebih dahulu melakukan evaluasi atau penilaian dengan observasi. Selanjutnya melakukan analisis data setelah semua data yang dibutuhkan telah terkumpul. Penelitian tindakan menggunakan pendekatan yang bersifat kualitatif (Sukmadinata, 2011). Teknik kualitatif ini digunakan untuk mendeskripsikan hasil dari keseluruhan siklus. Dalam penelitian ini, peneliti 
menggunkan teknik kualitatif agar dapat mengetahui proses kegiatan pembelajaran setelah data hasil observasi terkumpul kemudian dianalisis dan dipaparkan berdasarkan hasil pengamatan selama kegiatan pembelajaran.

Setelah tahap veripikasi dalam pengolahan data peneliti mengumpulkan hasil keterampilan berbicara anak dari penilaian perform berupa lembar kerja anak dan lembar aktivitas anak yang dilakukan oleh peneliti dalam proses pengembangan keterampilan berbicara, kemudian peneliti menghitung jumlah anak yang mendapatkan bintang 1, bintang 2, bintang 3 dan bintang 4 pada setiap indikator nya, kemudian dianalisis dengan menggunakan rumus sebagai berikut :

presentase $=\frac{\text { fumlah peserta didik yang tuntas }}{j u m l a h \text { peserta didik }} \times 100 \%$

\section{PEMBAHASAN}

Penelitian Tindakan Kelas ini, akan memperoleh hasil temuan dari setiap siklus yang telah dilaksanakan. Hasil penelitian ini kemudian dideskripsikan, dianalisis dan direfleksikan untuk mengetahui kekurangan setiap pembelajaran yang telah dilaksanakan. Sehingga hasil temuan tersebut dapat diketahui kekurangan dari setiap pembelajaran yang disampaikan terhadap anak dan membuat rencana dan pelaksanaan perbaikan yang dilakukan oleh guru.

Di dalam temuan penelitian penulis mencantumkan data-data temuan yang dikumpulkan sesuai dengan rumusan masalah yang di bahas dalam bab sebelumnya. Data temuan diambil dari hasil observasi selama melakukan pengamatan. Berikut ini adalah hasil temuan-temuan yang dikumpulkan peneliti selama proses pengamatan awal.

Temuan pertama dalam pengkondisian kelas dan apersepsi dirasakan belum kondusif mungkin sudah terbiasa dengan keadaan yang konvensional. Temuan kedua dalam proses pembelajaran ternyata siswa pasif kurang aktif dan kurang bergairah dalam belajar karena kegiatan yang dilakukan monoton seperti mendengarkan penjelasan guru. Temuan ketiga dalam tanya jawab siswa kurang percaya diri untuk mengemukakan pendapatnya.

Penelitian Tindakan Kelas (PTK) ini dimulai dari Tanggal 18 Mei 2015 sampai dengan 3 Juni 2015 di PAUD Tunas Unggulan kelompok B2 dengan jumlah siswa 17 siswa yang terdiri dari 8 anak laki-laki dan 9 anak perempuan. Selanjutnya dilakukan pra observasi untuk melihat kemampuan keterampilan berbicara anak. Peneliti akan meningkatkan keterampilan berbicara pada anak melalui media sosiodrama, agar keberhasilan peneliti dapat terlihat dengan jelas maka dilakukan pra observasi sebagai perbandingan sebelum dilakukan tindakan kelas dan sesudah tindakan kelas.

Pelaksanaan tindakan I kegiatan belajar mengajar di PAUD B dengan jumlah siswa yang hadir 11 siswa untuk siklus I yang terdiri dari 3 pertemuan. Siklus I tindakan I dilaksanakan pada hari Senin, Tanggal 18 Mei 2015 di kelompok B2 Paud Tunas Unggulan J1 Cemara Kecamatan Gede Bage Kota Bandung yang dimulai dari pukul 08.00-11.30 WIB. Sedangkan pelaksanaan tindakan II dilaksanakan pada hari selasa 19 Mei 2015 yang dimulai pada pukul 
08.00 -11.39 WIB, dan tindakan III dilaksanakan pada hari kamis 22 Mei 2015 yang dimulai pelaksanaannya pada pukul 08.00-11.30 WIB Kegiatan pembelajaran secara keseluruhan dilakukan dalam empat tahap kegiatan yaitu kegiatan awal, kegiatan inti, istirahat dan penutup.:

Berdasarkan hasil penelitian yang diperoleh, maka dapat disimpulkan hasil perkembangan keterampilan berbicara melalui metode sosiodrama pada siklus I sebagai berikut :

Tabel 4.1

Presentase Perkembangan Keterampilan Berbicara Anak Kelompok B2

Paud Tunas Unggulan Melalui Metode Sosiodrama Pada Siklus I

\begin{tabular}{|l|l|l|l|l|}
\hline \multirow{2}{*}{ SIKLUS I } & \multicolumn{2}{|c|}{ HASIL PENELITAN } & $\begin{array}{l}\text { Anak } \\
\text { yang } \\
\text { hadir }\end{array}$ \\
\cline { 2 - 5 } & $\star$ & $\star \star$ & $\begin{array}{l}\star \star \\
\star\end{array}$ & \\
\hline Tindakan 1 & $\begin{array}{l}45,4 \\
5 \%\end{array}$ & $\begin{array}{l}54,5 \\
5 \%\end{array}$ & $0 \%$ & 11 \\
\hline Tindakan 2 & $\begin{array}{ll}5,6 \\
7 \%\end{array}$ & $\begin{array}{l}58,3 \\
3 \%\end{array}$ & $0 \%$ & 12 \\
\hline Tindakan 3 & 26,6 & $60 \%$ & $\begin{array}{l}13,33 \\
\%\end{array}$ & 15 \\
\hline & $7 \%$ & & & \\
\hline
\end{tabular}

Dengan keterangan bintang 1 adalah belum berkembang (BB), bintang 2 mulai berkembang (MB), bintang 3 berkembang sangat baik (BSB). Dari tabel diatas perkembangan keterampilan berbicara anak melalui metode sosiodrama pada siklus I tindakan I jumlah bintang yang mendapatkan bintang 1 sebanyak $45,45 \%$, sedangkan pada tindakan $241,67 \%$, begitupun pada tindakan 3 yaitu sebanyak $26,67 \%$. Selanjutnya perolehan bintang 2 pada tindakan I sebanyak $54,55 \%$, pada tindakan 2 sebanyak 58,33\%, dan pada tindakan 3 sebanyak $60 \%$. Sedangkan untuk perolehan bintang 3 pada tindakan 1 sebanyak $0 \%$, pada tindakan 2 menjadi $0 \%$, dan pada tindakan 3 meningkat menjadi 13,33. Dilihat dari tabel tersebut perkembangan keterampilan berbicara anak melalui metode sosiodrama cukup baik dari sebelum peneliti melakukan penelitian dan melakukan pengamatan, namun untuk hasil yang lebih baik guru dapat meningkatkan kegiatan pemebelajaran ini.

Kegiatan pembelajaran siklus II tindakan I ini dilaksanakan pada hari Senin Tanggal 25 Mei 2015 pada pukul 08.0011.30 WIB. Tindakan II dilaksanakan pada hari Selasa 26 Mei 2015 pada pukul 08.0011.30 WIB, dan pada pelaksanaan tindakan III dilaksanakan pada hari Rabu 27 Mei 2015 yang dimulai pada pukul 08.00-11.30 WIB.

Berdasarkan hasil penelitian yang diperoleh, maka dapat disimpulkan hasil perkembangan keterampilan berbicara melalui metode sosiodrama pada siklus II sebagai berikut : 
Tabel 4.2

Presentase Perkembangan Keterampilan Berbicara Anak Kelompok B2 Paud Tunas Unggulan Melalui Metode Sosio rama Pada Siklus II

\begin{tabular}{|c|c|c|c|c|}
\hline \multirow[t]{2}{*}{ SIKLUS II } & \multicolumn{3}{|c|}{$\begin{array}{c}\text { HASIL } \\
\text { PENELITIAN }\end{array}$} & \multirow{2}{*}{\begin{tabular}{r|l} 
& $\begin{array}{l}\text { Anak } \\
\text { yang }\end{array}$ \\
$\star$ & hadir
\end{tabular}} \\
\hline & $\star$ & $\star \star$ & $\star$ & \\
\hline Tindakan 1 & $\begin{array}{l}11,7 \\
6 \%\end{array}$ & $\begin{array}{l}70,5 \\
9 \%\end{array}$ & $\begin{array}{l}17,6 \\
\%\end{array}$ & \begin{tabular}{l|l}
517 \\
\end{tabular} \\
\hline Tindakan 2 & $0 \%$ & $\begin{array}{l}76,4 \\
7 \%\end{array}$ & $\begin{array}{l}23,5 \\
3 \%\end{array}$ & 17 \\
\hline Tindakan 3 & $0 \%$ & $\begin{array}{l}70,5 \\
9 \%\end{array}$ & $\begin{array}{l}29,4 \\
1 \%\end{array}$ & 17 \\
\hline
\end{tabular}

Dengan keterangan bintang 1 adalah belum berkembang (BB), bintang 2 mulai berkembang (MB), bintang 3 berkembang sangat baik (BSB). Berdasarkan tabel 4.2 diatas perkembangan keterampilan berbicara anak melalui metode sosiodrama pada siklus II tindakan I jumlah bintang yang mendapatkan bintang 1 sebanyak $11,76 \%$, sedangkan pada tindakan 2 menurun menjadi $0 \%$, begitupun pada tindakan 3 menjadi 0\%. Selanjutnya perolehan bintang 2 pada tindakan I sebanyak 70,59\%, pada tindakan 2 sebanyak 76,47\%, dan pada tindakan 3 sebanyak 70,59\%. Sedangkan untuk perolehan bintang 3 pada tindakan 1 sebanyak 17,65\%, pada tindakan 2 sebanyak 23,53\%, dan pada tindakan 3 meningkat menjadi $29,41 \%$.. Dilihat dari tabel tersebut perkembangan keterampilan berbicara anak melalui metode sosiodrama ada perkembangan dan peningkatan dari siklus I, namun untuk hasil yang lebih optimal dalam mengembangkan keterampilan berbicara anak, guru sebaiknya dapat meningkatkan kegiatan pemebelajaran ini.

Kegiatan pembelajaran siklus III tindakan 1 dilaksanakan pada hari Kamis Tanggal 28 Mei 2015 pada pukul 08.0011.30 WIB, kegiatan tindakan II di dilaksanakan pada hari Jumat, Tanggal 29 Mei 2015, dan kegiatan tindakan III Rabu 3 Juni 2015 yang dimulai pada pukul 08.0011.30 WIB. Kegiatan pembelajaran secara keseluruhan dilakukan dalam empat tahap kegiatan yaitu kegiatan awal, kegiatan inti, istirahat dan penutup.

Berdasarkan hasil penelitian yang diperoleh, maka dapat disimpulkan hasil perkembangan keterampilan berbicara melalui metode sosiodrama pada siklus II sebagai berikut : 
Tabel 4.3

Presentase Perkembangan Keterampilan Berbicara Anak Kelompok B2 Paud Tunas Unggulan Melalui Metode Sosiodrama Pada Siklus III

\begin{tabular}{|l|l|l|l|l|}
\hline \multirow{2}{*}{ SIKLUS III } & \multicolumn{3}{|c|}{ HASIL } & $\begin{array}{l}\text { Anak } \\
\text { yang }\end{array}$ \\
\cline { 2 - 5 } & $\star$ & $\star \star$ & $\begin{array}{l}\star \star \\
\text { PENELITI } \\
\text { hadir }\end{array}$ & \\
\hline Tindakan 1 & 11,7 & 52,9 & 35,29 & 17 \\
& $7 \%$ & $4 \%$ & $\%$ & \\
\hline Tindakan 2 & $0 \%$ & $\begin{array}{l}52,9 \\
4 \%\end{array}$ & $\begin{array}{l}47,06 \\
\%\end{array}$ & 17 \\
\hline Tindakan 3 & $0 \%$ & $\begin{array}{l}23,5 \\
3 \%\end{array}$ & $\begin{array}{l}76,47 \\
\%\end{array}$ & 17 \\
\hline
\end{tabular}

Dengan keterangan bintang 1 adalah belum berkembang (BB), bintang 2 mulai berkembang (MB), bintang 3 berkembang sangat baik (BSB). Dari tabel diatas perkembangan keterampilan berbicara anak melalui metode sosiodrama pada siklus III tindakan I jumlah bintang yang mendapatkan bintang 1 sebanyak $11,77 \%$, sedangkan pada tindakan 2 menurun menjadi $0 \%$, begitupun pada tindakan 3 menjadi 0\%. Selanjutnya perolehan bintang 2 pada tindakan I sebanyak 52,94\%, pada tindakan 2 sebanyak 52,94\%, dan pada tindakan 3 kembali menurun menjadi 23,53\%. Sedangkan untuk perolehan bintang 3 pada tindakan 1 sebanyak 35,29\%, pada tindakan 2 meningkat menjadi 47,06\%, dan pada tindakan 3 menurun menjadi 76,47\%. Dilihat dari tabel diaatas tersebut perkembangan keterampilan berbicara anak melalui metode sosiodrama mengalami perkembangan dan peningkatan yang sangat signifikan dari siklus I ke siklus II kemudian siklus III.

\section{Pembahasan}

Pada penelitian ini, peneliti menggunakan Penelitian Tidakan Kelas (PTK) yang dilaksanakan pada tiga siklus yang masing- masing siklusnya terdiri dari tiga tindakan. Berdasarkan hasil penelitian pada Siklus I, Siklus II, dan Siklus III yang dilaksanakan di Paud Tunas Unggulan Jl Cemara Kecamatan Gede Bage Kota Bandung yang dimulai pada tanggal 18 Mei 2015 sampai dengan tanggal 3 Juni 2015 menghasilkan data yang sangat baik, dimana setelah dilaksanakanya penelitian berkenaan dengan keterampilan berbicara anak mengalami perkembangan. Adapun target dari penelitian yang dilaksanakan ini sesuai dengan indikator yang digunakan yaitu, (pengucapan) Anak mampu berkomunikasi secara lisan memiliki perbendaharaan kata, serta mengenai simbol-simbol untuk persiapan membaca, menulis dan berhitung. Selanjutnya (keberanian) Anak berani mengungkapkan keinginannya, penolakannya, maupun pendapatnya 
melanjutkan sebagian cerita/dongeng yang telah diperdengarkan. Berikutnya Ekspresi atau bahasa tubuh (Anak bisa Mengekspresikan emosi yang sesuai dengan kondisi yang ada (senang-sedih- antusias dsb).

Peneliti memperoleh hasil dari perkembangan keterampilan berbicara, hasil dari perolehan pelaksanaan pada tindakan 3 siklus 3 peneliti merasa cukup dan anak juga sudah merasa bosan. Perkembangan keterampilan berbicara anak diukur dari penilaian anak berdasarkan indikator yang dilaksanakan sampai tiga tindakan. Adapun hasil dari pembelajaran siklus I, II sampai III dapat dilihat dari grafik sebagai berikut :

\section{Gambar 4.1 Perkembangan Keterampilan Berbicara Anak Pada Siklus I} sampai dengan siklus III

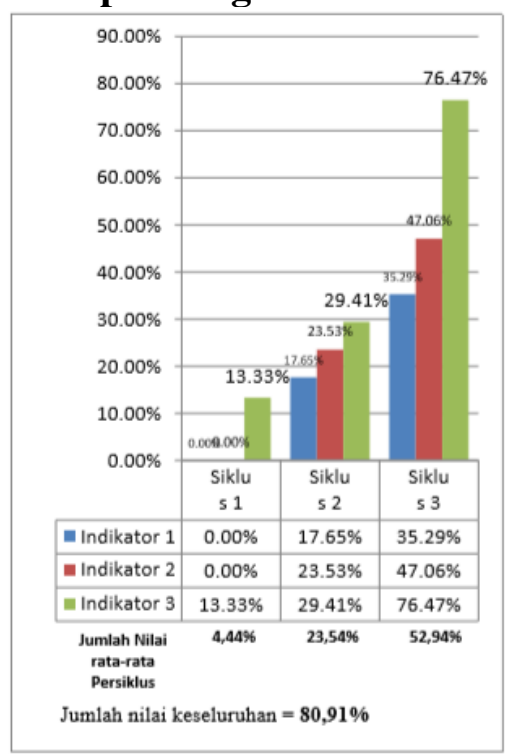

Berdasarkan grafik 4.4. Pada perkembangan keterampilan berbicara anak yang diambil yaitu dari setiap tindakan pada kegiatan inti pembelajaran ketiga. Pada siklus I tindakan I anak yang mencapai bintang 3 sebesar 0\%, pada tindakan II, yang mencapai bintang 3 sebesar 0\%, sedangkan pada tindakan ke III yang mendapatkan bintang 3 sebanyak 13,33\%. Hasil pembelajaran pada siklus pertama yang diperoleh anak masih sangat kurang. Hal ini dikarenakan anak masih baru mengenal pembelajaran metode sosiodrama. Kemudian pada siklus ke dua perkembangan anak meningkat, dimana pada tindakan I yang mencapai bintang 3 sebanyak 17,65\%, kemudian pada tindakan yang mendapatkan bintang 3 sebanyak 23,53\%. Selanjutnya pada tindakan III siklus II kembali mengalami perkembagan sebanyak $29,41 \%$. Meningkat $16.08 \%$ dari siklus sebelumnya yaitu siklus I. Dilanjutkan pada proses pembelajaran siklus III, pada siklus III ini dikarenakan sering dilaksanakan dengan cara bertahap anak kini sudah mulai paham dan mengerti, hal ini dilihat dari perkembangan anak dari setiap siklus nya. Pada siklus III tindakan 1 yang mendapatkan bintang 3 sebanyak 35,29\%, meningkat dari siklus sebelumya yaitu siklus II, yang dimana pada siklus II sebanyak $17,65 \%$. Kemudian pada tindakan II siklus III pun mengalami 
peningkatan yang cukup signifikan, yang dimana pada siklus III tindakan II yang mencapai bintang 3 sebanyak 47,06\%. Selanjutnya pada tindakan III mengalami peningkatan yang sangat signifikan dari siklus sebelumnya, pada siklus III tindakan ini yang mencapai bintang 3 sebanyak 76,47\% meningkat sebanyak $47,06 \%$ dari siklus sebelumnya yaitu siklus II sebanyak $29,41 \%$, untuk jumlah nilai secara keseluruhan sebesar $80.91 \%$.

\section{PENUTUP}

Berdasarkan data-data yang telah ditemukan, peneliti mengemukakan kesimpulan dari penelitian yang telah dilaksanakan. Simpulan ini merupakan jawaban dari rumusan masalah yang telah diuraikan. Simpulan ini dipaparkan berdasarkan kegiatan pembelajaran melalui metode sosiodrama untuk mengembangkan keterampilan berbicara anak pendidikan anak usia dini.

Adapun simpulan dari penelitian ini yaitu sebagai berikut:

1. Proses pembelajaran bersosiodrama yang dimain perankan oleh setiap anak terhadap keterampilan berbicara anak mengalami perkembangan. Hal ini dilihat ketika anak berperan aktif dalam mengikuti kegiatan sosiodrama anak mampu mengikuti kegiatan dari awal sampai akhir, anak mengikuti kegiatan dengan penuh semangat, riang dan gembira. Anak mendapatkan penilaian dari indikator yang ditentukan. Indikator yang digunakan dalam penilaian yaitu pengucapan (Anak mampu berkomunikasi secara lisan), Keberanian (Anak berani mengungkapkan keinginannya, penolakannya, maupun pendapatnya) dan ekspresi atau bahasa tubuh (anak bisa mengekspresikan diri melalui drama bercerita menggunakan kalimat dengan berekspresi). Proses dari setiap tindakan yang dilakukan oleh anak mengalami perkembangan pada keterampilan berbicara. Hal ini dilihat dari perkembangan keterampilan berbicara anak pada akhir siklus I hanya mencapai kategori rendah, mulai mengalami peningkatan diakhir pelaksanaan siklus II menjadi sedang dan selanjutnya pada akhir siklus I mengalami peningkatan hingga dikategorikan sangat tinggi, atau berkembang sangat baik.

2. Aktivitas siswa dalam pembelajaran juga mengalami peningkatan, yang dimana pada siklus I tindakan I anak tidak bermain dalam melaksanakan drama, anak dapat menirukan dan mengekspresikan gerakan dengan baik dan benar, anak menunjukan sikap riang dan gembira, selalu bersemangat ketika bermain peran sambil bersosiodrama, anak selalu antusias mengikuti pembelajaran dan anak mengikuti kegiatan dari awal sampai akhir belum berkembang, hal ini dikarenakan anak masih baru dan canggung dengan metode yang digunakan. Pada tindakan II dan III anak menunjukan sikap riang dan gembira menunjukan mulai berkembang, begitupun anak selalu bersemangat ketika bermain peran sambil bersosiodrama dan anak mengikuti kegiatan dari awal sampai akhir mengalami peningkatan dari belum berkembang menjadi mulai berkembang. Namun pada siklus III aktivitas anak mengalami perkembangan, semua anak sudah mulai paham dan mengerti dengan metode yang guru terapkan dalam pembelajaran, anak tidak bermain dalam melaksanakan drama, anak dapat menirukan dan mengekspresikan gerakan dengan baik dan benar, anak menunjukan sikap 
riang dan gembira, selalu bersemangat ketika bermain peran sambil bersosiodrama, anak selalu antusias mengikuti pembelajaran dan anak mengikuti kegiatan dari awal sampai akhir mencapai skala kemunculan berkembang sangat baik 3 . Hasil perkembangan keterampilan berbicara anak dari kegiatan pembelajaran melalui metode sosiodrama mengalami peningkatan atau perkembangan. Hal ini terlihat dari instrument yang didapat dari hasil observasi, wawancara, dan catatan lapangan selama berlangsungnya kegiatan pembelajaran inti. Selain itu perkembangan keterampilan berbicara anak melalui metode sosiodrama dapat dilihat dari hasil perolehan anak dari setiap siklus nya. Pada siklus I tindakan I yang mendapatkan bintang 3 sebanyak $0 \%$, pada tindakan II $0 \%$, tetapi ada perkembangan pada tindakan III sebesar 13,33\%. Pada siklus II tindakan I yang mendapatkan bintang 3 sebanyak $17,65 \%$, pada tindakan II sebesar $23,53 \%$, sedangkan pada tindakan 3 sebanyak 29,41\%. Dan pada siklus III tindakan 1 yang mendapatkan bintang 3 sebanyak 35,29\%, meningkat pada tindakan II sebanyak 47,06\%, kemudian meningkat lagi pada tindakan 3 menjadi 76,47\%. Dari hasil penelitian ini, hasil yang didapat dari setiap siklusnya mengalami peningkatan dari setiap siklus tindakannya. Peningkatan ini mencerminkan bahwa dengan menggunakan metode sosiodrama dapat mengembangkan keterampilan berbicara anak.

\section{DAFTAR PUSTAKA}

Abidin, Y. (2011). Penelitian Pendidikan Dalam Gamintan Pendidikan Dasar dan Paud.Bandung: Rizqi Press.

Tarigan, H. G. (1986! Pengajaran Ejaan Bahasa Indonesia. Bandung: Angkasa

Tarigan, H. G. (1986). Keterampilan Berbicara. Bandung: Angkasa.

Kemendiknas. (2010). Kurikulum Taman Kanak-Kanak. Jakarta: Direktorat Pembinaan TK dan SD

Peraturan Menteri Pendidikan Nasional Nomor 58. (2010). Tentang Standar Pendidikan Anak Usia Dini. Jakarta. Kemendiknas.

Sudjana, N. (2002), Dasar-Dasar Proses Belajar Mengajar, Bandung : Sinar Baru Algesindo

Arikunto, S. (2014). Penelitian Tindakan Kelas .Jakarta : Bumi PT Bumi Aksara

Tamin, S. (2009). Pendekatan Student Center dalam Pembelajaran. Diakses dari

http://www.fai.umj.ac.id/index.ph p?option=com_content\&task=vie w\&id=3 7\&Itemid=54. Pada tanggal 13 Desember 2014, jam 08.05 WIB.

Sukmadinata, N. S. (2011). Metode Penelitian Pendidikan. Bandung: PT Remana Rosdakarya.

UUD RI Nomor 20 Tahun 2003. tentang Sistem Pendidikan Nasional. Jakarta.

Yuliani, N. S. (2009). Konsep Dasar Pendidikan Anak Usia Dini. Jakarta : Indek. 